ELŻBIETA NAPORA ${ }^{1}$

Zakład Psychologii, Instytut Filozofii, Socjologii i Psychologii

Akademia im. Jana Długosza w Częstochowie

Studia Psychologica

UKSW

16(2) 2016 s. $43-57$

\title{
UWARUNKOWANIA ATRAKCYJNOŚCI DZIECKA WŚRÓD RÓWIEŚNIKÓW
}

\begin{abstract}
STRESZCZENIE
Celem badań było uchwycenie czynników różnicujących atrakcyjność dziecka wśród rówieśników. Oczekiwano, że cechy związane z dzieckiem i z rodziną będą różnicować zarówno jego wybory pozytywne, jak i negatywne przez rówieśników oraz rodzaje jego atrakcyjności w grupie. Przebadano 192 uczniów w wieku 11-13 lat przy zastosowaniu socjometrycznego testu Morena. Wyniki pokazały, że sytuacja materialna rodziny wiąże się $\mathrm{z}$ atrakcyjnością dziecka w grupie. Dzieci bardziej interesują się tymi rówieśnikami, którzy są lepiej sytuowani materialnie. Gorsza sytuacja materialna rodziny istotnie wiąże się z niekompletną rodziną oraz z płcią dziecka. Uzyskane wyniki można ujmować w szerszym kontekście zjawisk społecznych, wywoływanych zróżnicowaniem wysokości dochodów w rodzinach. Efekty sugerują, że dzieci z rodzin zamożnych nie tylko cieszą się większą popularnością wśród rówieśników, lecz także mają lepszą sytuację edukacyjną i łatwiejszą drogę do osiągania zaplanowanych celów.
\end{abstract}

Słowa kluczowe: dziecko w grupie rówieśniczej, sytuacja materialna rodziny

\section{CONDITIONS THAT INFLUENCE CHILDREN'S POPULARITY AMONG PEERS}

\section{SUMMARY}

The purpose of this study was to determine which factors influence varied popularity of children among their peers. It was expected that the traits of the child and its family will affect both the positive and the negative reactions of the peers, and that they will influence the type of the child's popularity in the group. The sample for the current study included 192 students aged 11-13. Moreno's sociometric test was used to conduct the study. The results showed that the material situation of the family is related to the child's popularity in the group, as children tend to like more those from well-to-do families. Lower economic status is more frequently observed in incomplete families and is perceived much more negatively by boys than by girls.

The obtained results should be analyzed from the point of view of a broader context of social issues caused by the differences in the families' incomes. The results of the study suggest that children from wealthy families are not only more popular among

1 Adres do korespondencji: e.napora@ajd.czest.pl. 
their peers, but they also perform better academically and have better prospects of reaching their goals.

Keywords: child among peers, material situation of a family

\section{WPROWADZENIE}

Badacze podkreślają wskaźniki charakteryzujące pod względem jakościowym środowisko wychowawcze dziecka. Jakość tego środowiska odgrywa ważną rolę w rozwoju i utrzymaniu dobrych relacji z rówieśnikami (Napora, Pękala, 2014). Wśród wskaźników wymienia się m.in.: stopień więzi uczuciowej dziecka z rodzicami (Pawłowska, 1994), sytuację materialną rodziny, jej strukturę i wielkość (Kwak, 2008-2009; Lenarczyk, 2004). Warunki materialne rodziny „odbijają się” na dziecku (Bartczak, 2014). Gorsza sytuacja materialna wiąże się negatywnie z jego wychowaniem (Białas, 2001) i rodzi niską samoocenę (Raczkowska, 1994), koreluje z zaburzeniami psychicznymi, nieprawidłowymi relacjami rodzice-dziecko, częstymi przypadkami zaniedbywania dziecka (J. J. McWhirter, E. H. McWhirter, A. M. McWhirter, B. T. McWhirter, 2008).

Sztumski zaobserwował, że dzieci i młodzież, które wzrastają w warunkach biedy, są również gorzej rozwinięte pod względem fizycznym, mają większą skłonność do różnych schorzeń i ograniczone zaufanie do własnych możliwości (2006). W rodzinach dotkniętych ubóstwem obserwuje się niesatysfakcjonującą relację matki i dziecka (Miller, Davis, 1997). Co więcej, trudności finansowe samotnej matki można identyfikować $\mathrm{z}$ mniej efektywnym funkcjonowaniem rodziny, które wiąże się z negatywnymi skutkami dla dziecka (Elder, Eccles, Ardelt, Lord, 1995) także w rodzinach pełnych. Dzieci w rodzinach dotkniętych niedostatkiem, wskutek braku środków na zaspokojenie potrzeb, nie tylko materialnych, czują się gorsze od swoich rówieśników (Cudak, Kowolik, Pindera, 1999). Taka sytuacja często prowadzi do stopniowej izolacji środowiskowej i ograniczenia kontaktów z kolegami. Dzieci z rodzin o niskim statusie społeczno-ekonomicznym wskazują, że szkoła jest dla nich środowiskiem nieprzyjaznym, terenem niezdrowej rywalizacji i źródłem złego samopoczucia (Zawada, 2002).

Ubóstwo prowadzi do większego stresu emocjonalnego i pogarsza satysfakcję z życia rodzinnego (Kotowska, Matysiak, Styrc, 2012; Mazur, Woynarowska, 2004; Napora, Kozerska, Schneider, 2014), obniża poczucie własnej wartości w oczach rówieśników (Napora i in., 2014). Biorąc pod uwagę oceny zamożności rodzin, badacze uchwycili liniowy wzrost odsetka młodzieży oceniającej pomoc rodziców jako niską: od 5,1\% w rodzinach bogatych lub raczej bogatych do 28,6\% w rodzinach biednych lub raczej biednych. Zależność ta jest istotna u obu płci (Mazur, Woynarowska, 2004).

Dzieci z rodzin ubogich często są pozbawione uczuciowego związku z rodzicami, narażone są też na zaburzenia rozwoju osobowości. Więź między rodzicami i dziećmi słabnie, a wzrasta potencjalne zagrożenie wystąpienia 
niedostosowania społecznego (Urban, 2005). W konsekwencji zachowania agresywne przekształcają się w stałą tendencję i zostają włączone do stylu życia dziecka. Osoby niemające poczucia przynależności do grupy mają problemy $\mathrm{w}$ relacjach interpersonalnych, przejawiają ostrzejsze symptomy depresyjne oraz niską samoocenę (Urban, 2005). Pogarsza to i ogranicza kontakty koleżeńskie oraz rodzi izolację społeczną (Cudak i in., 1999).

Badacze uchwycili zależność między korzystną oceną sytuacji materialnej rodziny a wyższym poczuciem bezpieczeństwa, miłości i zrozumienia, deklarowanymi przez młodzież. Satysfakcjonujące stosunki z rodzicami są związane $\mathrm{z}$ ich wyższym poziomem wykształcenia, lepszą sytuacją materialną rodziny oraz wyższą pozycją społeczną ojca (Kwak, 2008-2009). Satysfakcjonująca ocena statusu materialnego rodziny nie ma wpływu na relacje córek z rówieśniczkami w grupie (Napora i in., 2014).

Wczesna adolescencja (Kwak, 2008-2009) lub preadolescencja (Radziwiłłowicz, 2012) to czas od 10-12 lat do 15 r.ż., charakteryzujący się wyraźnym dojrzewaniem fizycznym i wzrostem zapotrzebowania na kontakty $z$ innymi. Relacje $\mathrm{z}$ rówieśnikami zaspokajają wiele potrzeb społecznych nastolatków, w tym potrzebę przynależności, sukcesu, akceptacji i uznania oraz odgrywania ról (Jundził, 1998). Stanowią też okazję do rozwijania umiejętności społecznych: komunikowania się, współpracy, empatii, okazywania i otrzymywania wsparcia, rozwiązywania konfliktów, negocjowania. Rozwój kompetencji społecznych $\mathrm{w}$ grupie umożliwia lepsze rozumienie sytuacji społecznych, poszerzenie wiedzy o zjawiskach społecznych, rozwój wnioskowania społecznego i trening ról społecznych (Harwas-Napierała, Trempała, 2006; Kulawska, 2013).

Nastolatki często utożsamiają się z rówieśnikami, podobnie spędzają czas wolny, podobnie się ubierają. Rówieśnicy wpływają w większym stopniu na styl życia młodzieży niż na wybór wartości, na którym to wyborze znacznie bardziej zaważają rodzice, mimo licznych konfliktów ze swoimi dorastającymi dziećmi (Obuchowska, 2000). Dzieci, które nie mogą dorównać rówieśnikom, np. w posiadaniu atrakcyjnych przedmiotów, często nie są akceptowane w szkole i poza nią (Matyjas, 2003).

Klasa szkolna jako grupa społeczna wywiera znaczący wpływ na swoich członków. Od jej struktury, stosunków społecznych i więzi emocjonalnych zależy rozwój osobowości uczniów. Pozycja dziecka w grupie w pewnym stopniu wypływa z zachowań już ukształtowanych, jednak cechy osobowości kształtują się lub utrwalają przede wszystkim w grupie. Biorąc pod uwagę czas, jaki uczniowie spędzają w klasie, warto podkreślić istotę prawidłowego funkcjonowania klasy szkolnej jako mającej siłę oddziaływania wychowawczego (Zawada, 2013). Efekty badań Samdal i Düra pokazały, że uczniowie, którzy spostrzegają szkołę pozytywnie, osiągają lepsze wyniki w nauce i mają ze szkoły większą satysfakcję (2000). 
W badaniu pozycji społecznej można określić rodzaj statusu socjometrycznego, klasyfikując uczniów do jednej z trzech kategorii: (1) dzieci popularne/ atrakcyjne, (2) odrzucane, (3) kontrowersyjne/z przeciętną akceptacją (Kulawska, 2013). W badaniach socjometrycznych pierwsze $\mathrm{z}$ nich otrzymują dużo wyborów pozytywnych, a mało negatywnych i rzadko są wskazywane jako nielubiane. Analiza profili behawioralnych wskazuje, że dzieci te najczęściej są atrakcyjne fizycznie, mają optymistyczne i radosne usposobienie, cechują się gotowością do dzielenia $z$ innymi i do współpracy, a także niskim poziomem agresji. Charakteryzuje je towarzyskość i przyjazne nastawienie wobec innych, a ich zachowanie nie wzbudza agresji (Schaffer, 2006). Popularność jest cechą, której nasilenie można opisać na jednowymiarowym kontinuum: na jednym krańcu są dzieci akceptowane przez grupę, a na drugim - dzieci odrzucane (Dodge i in., 2003).

Dzieci odrzucane nie potrafią nawiązać interakcji z rówieśnikami, wiele $\mathrm{z}$ nich przejawia destrukcyjne zachowania, często antyspołeczne i agresywne wobec innych dzieci. Mają tendencję do unikania kontaktów z innymi, rzadko podkreślają swoje prawa. Inne cechy charakteryzujące tych uczniów to częste symptomy depresyjne, wysoki poziom lęku społecznego, niskie poczucie kompetencji społecznych (Schaffer, 2006). Dzieci te są również opisywane jako nieśmiałe, małomówne. Wśród odrzuconych - biorąc pod uwagę płeć dziecka chłopcy częściej niż dziewczynki byli opisywani jako agresywni i dokuczliwi (Napora, 2015; Napora, Garbiec, 2015, V, w druku).

W obecnych czasach, nacechowanych konsumpcjonizmem i zmianami w strukturze rodziny, wyniki mogą wskazać zależność między warunkami funkcjonowania rodziny dziecka a jego atrakcyjnością wśród rówieśników.

Celem podjętych badań było wskazanie cech różnicujących status socjometryczny dziecka w klasie. Oczekiwano, że te związane z dzieckiem, jak i z rodziną różnicują zarówno wybory pozytywne, jak i negatywne dziecka przez rówieśników oraz rodzaje statusu socjometrycznego w grupie. Główny problem badawczy sformułowano w postaci pytania: Czy cechy związane z dzieckiem (płeć, wiek) oraz z rodziną (struktura rodziny, subiektywny status materialny, miejsce zamieszkania, liczba rodzeństwa) różnicują pozycję socjometryczną wśród rówieśników? Problem sprowadzono do trzech pytań szczegółowych: 1. Które analizowane cechy różnicują pozytywne, a które negatywne wybory dziecka przez rówieśników, a jeśli tak, to czy mają istotne oddziaływanie? 2. Które cechy istotnie różnicują pozycje socjometryczne dziecka wśród rówieśników? oraz 3. Które $\mathrm{z}$ badanych cech wykazują związek $\mathrm{z}$ cechami istotnie różnicującymi akceptację dziecka przez rówieśników w klasie? 


\section{MetOdA BADAwCZA}

\section{Osoby badane}

W badaniu udział wzięło 192 uczniów szkół podstawowych w wieku 11-13 lat, z 10 szkół: sześciu szkół wiejskich i z czterech szkół małomiasteczkowych. Dane dotyczące uczestników badania przedstawiono w tabeli 1 .

Tabela 1

Charakterystyka badanych dzieci

\begin{tabular}{llcc}
\hline Lp. & Czynniki rodziny & \multicolumn{2}{c}{ Statystyki opisowe } \\
\hline 1. & Wiek dziecka & $\mathrm{M}$ & 11,9 \\
& & $\mathrm{SD}$ & 0,82 \\
2. & Płeć: & & \\
& chłopcy & 89 & $46,4 \%$ \\
& dziewczęta & 103 & $53,6 \%$ \\
3. & & \\
& Struktura rodziny: & 162 & $84,4 \%$ \\
& pełna & 30 & $15,6 \%$ \\
& rodzina samotnej matki & & \\
4. & Status materialny: & 29 & $15,1 \%$ \\
& niezadowalający & 125 & $65,1 \%$ \\
& wystarczający & 38 & $19,8 \%$ \\
& bardzo dobry & & \\
5. Zamieszkanie: & 110 & $57,3 \%$ \\
& wieś & 82 & $42,7 \%$ \\
& miasto & & \\
6. & Liczba rodzeństwa: & 36 & $18,8 \%$ \\
& brak & 126 & $65,7 \%$ \\
& 1-2 & 30 & $15,7 \%$ \\
\hline
\end{tabular}

Najwięcej dzieci pochodziło z rodzin pełnych $(n=162 ; 84,4 \%)$, które oceniły status materialny rodziny jako wystarczający $(n=125 ; 65,1 \%)$. Dzieci w większości mieszkały na wsi $(n=110 ; 57,3 \%)$, w rodzinie z jednym bądź dwojgiem rodzeństwa $(n=126 ; 65,7 \%)$. Wśród badanych wyraźnie dominowały dziewczęta $(n=105 ; 54,7 \%)$.

\section{Sposób przeprowadzenia badań}

Badania $^{2}$ prowadzono w 2013 roku. Rodziców proszono o zgodę na udział ich dzieci w pracach, informowano o ich celu i oczekiwanych korzyściach.

2 Badania przeprowadziła Paulina Garbiec w ramach bezkosztowego projektu Ubóstwo rodzin z prowincjonalnej Polski, realizowanego w latach 2013-2014. 
Po uzgodnieniu z dyrektorami szkół i wychowawcami klas poprowadzono badania. Dzieci zapewniono o anonimowości wyników, jak i możliwości wycofania się w każdej chwili z udziału, bez ponoszenia jakichkolwiek konsekwencji.

\section{Narzędzia}

Socjometria służy m.in. do ustalenia pozycji ucznia w klasie oraz rozpoznania stosunków społecznych w grupie. Pozwala określić wzajemne sympatie lub antypatie, popularność lub jej brak, a także wyodrębnić cechy i właściwości mówiące o koleżeństwie, atrakcyjności lub przywództwie w grupie. Tworzy możliwość wglądu w postawy emocjonalne badanych osób. Zastosowane pytania i polecenia dotyczyły konkretnych odpowiedzi w danych sytuacjach, określających stosunki społeczne w grupie i między poszczególnymi jej członkami (Apanowicz, 2002). Wykorzystany test socjometryczny J. L. Morena składał się z dwóch części: pierwszej, stanowiącej metryczkę, w której uczniowie byli pytani o wiek, płeć, strukturę rodziny, jej status materialny ${ }^{3}$, liczbę rodzeństwa oraz miejsce zamieszkania, oraz z części drugiej, w której wykorzystano sześć pytań z uwzględnieniem trzech socjometrycznych kryteriów wyboru:

1. Wychowawca zlecił wykonanie gazetki świątecznej. (1a) Wybierz z klasy trzy osoby, które poprosiłbyś/poprosiłabyś o pomoc w jej przygotowaniu. (lb) Wybierz z klasy trzy osoby, które najmniej chętnie poprosiłbyś/poprosiłabyś o pomoc w jej przygotowaniu.

2. Wyobraź sobie, że jedziesz z klasą na trzydniową wycieczkę do Krakowa. (2a) Wybierz z klasy trzy osoby, obok których chciałbyś/chciałabyś siedzieć $\mathrm{w}$ autobusie. (2b) Wybierz z klasy trzy osoby, obok których najmniej chętnie chciałbyś/chciałabyś siedzieć w autobusie.

Oraz (3a) Wybierz z klasy trzy osoby, z którymi chciałbyś/chciałabyś mieszkać w jednym pokoju podczas pobytu w Krakowie. (3b) Wybierz z klasy trzy osoby, z którymi najmniej chętnie chciałbyś/chciałabyś mieszkać $\mathrm{w}$ jednym pokoju podczas pobytu w Krakowie.

Zadaniem każdego ucznia było dokonanie wyborów pozytywnych i negatywnych wśród rówieśników z klasy do każdego z kryterium. Przy każdym kryterium proszono dzieci o uzasadnienie swoich wyborów. W oparciu o wyniki rozróżniono trzy rodzaje pozycji socjometrycznej: z wysoką akceptacją/ atrakcyjny ( $n=77 ; 40,1 \%$, do grupy zaliczono uczniów z dużą liczbą wyborów pozytywnych i niską negatywnych), z przeciętną ( $n=54 ; 28,1 \%$, dzieci z mniej więcej taką samą liczbą wyborów pozytywnych i negatywnych) oraz z niską akceptacją/nieatrakcyjny ( $n=61 ; 31,8 \%$, dzieci z dużą liczbą wyborów negatywnych i niską pozytywnych).

3 Pytanie o status materialny rodziny zostało ograniczone do jednego zamkniętego (przekodowanego później) pytania o ocenę sytuacji materialnej rodziny, z zaznaczeniem jednej $\mathrm{z}$ trzech możliwych odpowiedzi. 


\section{WYNIKI}

Analizy statystyczne przeprowadzono za pomocą programu Statistica 10.0 (StatSoft Inc., 2011). Zgodność rozpatrywanych zmiennych ilościowych z rozkładem normalnym badano przy użyciu testu Shapiro-Wilka. $Z$ uwagi na to, iż rozkłady istotnie odbiegały od rozkładu normalnego, a dodatkowo liczebność obu porównywanych grup była różna, do weryfikacji hipotez zastosowano metody nieparametryczne. Do porównań między dwiema grupami wykorzystano test $U$ Manna-Whitneya $(z)$, w sytuacji porównań dla większej liczby grup użyto ANOVA rang Kruskala-Wallisa $(H)$. Analizę zależności między zmiennymi reprezentowanymi na skalach jakościowych wykonano testem chi-kwadrat.

\section{Cechy rodzinne i osobowe a atrakcyjność dziecka w grupie}

Wynik analizy istotny statystycznie $(H[2,192]=9,39 ; p=0,009)$ dotyczył statusu materialnego i pokazał jego istotny wpływ na liczbę pozytywnych wyborów dziecka przez rówieśników. Status materialny rodziny nie miał znaczącego wpływu na wybory negatywne. Warto zwrócić uwagę, że płeć, chociaż nie była cechą różnicującą istotnie liczbę wyborów pozytywnych, to jednak przyniosła wynik bliski granicy istotności statystycznej $(z=1,69 ; p=0,09)$. Wartość objaśniająca pozytywne $(M=9,66 ; S D=7,11)$ i negatywne $(M=7,83 ; S D=9,92)$ wybory dziewczynek wskazywała na ich odwróconą proporcję w porównaniu z wyborami chłopców (kolejno $M=7,84 ; S D=5,85$ i $M=9,75 ; S D=11,68$; tabela 2).

Wpływ statusu materialnego na pozytywne wybory dziecka przez rówieśników sprawdzono testem post-hoc, weryfikującym, między którymi grupami zachodzi istotna różnica. Wyniki zawiera tabela 2.

Tabela 2

Cechy różnicujące pozytywne i negatywne wybory dziecka

\begin{tabular}{|c|c|c|c|c|c|c|c|c|c|}
\hline \multirow{2}{*}{ Lp. } & \multirow{2}{*}{ Cechy } & \multicolumn{3}{|c|}{ Wybory pozytywne } & \multirow{2}{*}{$p$} & \multicolumn{3}{|c|}{ Wybory negatywne } & \multirow{2}{*}{$p$} \\
\hline & & $M$ & Me & $S D$ & & $M$ & Me & $S D$ & \\
\hline \multirow[t]{3}{*}{1.} & Płeć: & & & & & & & & \\
\hline & dziewczynki & 9,66 & 9,0 & 7,11 & 0,09 & 7,83 & 5,0 & 9,92 & 0,38 \\
\hline & chłopcy & 7,84 & 8,0 & 5,85 & & 9,75 & 5,0 & 11,86 & \\
\hline \multirow[t]{4}{*}{2.} & Wiek w latach: & & & & & & & & \\
\hline & 11 & 8,92 & 8,0 & 7,17 & & 8,68 & 5,0 & 11,3 & \\
\hline & 12 & 8,74 & 8,0 & 6,9 & 0,85 & 8,86 & 5,0 & 12,29 & 0,26 \\
\hline & 13 & 8,77 & 9,0 & 5,53 & & 8,63 & 6,0 & 8,72 & \\
\hline
\end{tabular}

Ciąg dalszy tabeli na następnej stronie 
Ciąg dalszy tabeli z poprzedniej strony

\begin{tabular}{|c|c|c|c|c|c|c|c|c|c|}
\hline \multirow{2}{*}{ Lp. } & \multirow{2}{*}{ Cechy } & \multicolumn{3}{|c|}{ Wybory pozytywne } & \multirow{2}{*}{$p$} & \multicolumn{3}{|c|}{ Wybory negatywne } & \multirow{2}{*}{$p$} \\
\hline & & $M$ & Me & $S D$ & & $M$ & Me & $S D$ & \\
\hline \multirow[t]{3}{*}{3.} & $\begin{array}{l}\text { Struktura } \\
\text { rodziny: }\end{array}$ & & & & & & & & \\
\hline & pełna & 8,95 & 8,0 & 6,62 & 0,49 & 8,09 & 5,0 & 10,17 & 0,29 \\
\hline & $\begin{array}{l}\text { rodzina samotnej } \\
\text { matki }\end{array}$ & 8,1 & 7,5 & 6,56 & & 12,13 & 7,0 & 13,81 & \\
\hline \multirow[t]{4}{*}{4.} & $\begin{array}{l}\text { Status } \\
\text { materialny: }\end{array}$ & & & & & & & & \\
\hline & niezadowalający & 7,58 & 7,0 & 7,22 & & 13,72 & 10,0 & 15,08 & \\
\hline & wystarczający & 8,21 & 8,0 & 5,89 & 0,009 & 7,99 & 5,0 & 9,99 & 0,11 \\
\hline & bardzo dobry & 11,66 & 12,0 & 7,62 & & 7,33 & 5,0 & 9,0 & \\
\hline \multirow[t]{3}{*}{5.} & Zamieszkanie: & & & & & & & & \\
\hline & wieś & 8,78 & 8,0 & 6,9 & 0,76 & 8,75 & 5,0 & 11,26 & 0,69 \\
\hline & miasto & 8,87 & 8,5 & 6,23 & & 8,68 & 5,0 & 10,41 & \\
\hline \multirow[t]{4}{*}{6.} & $\begin{array}{l}\text { Liczba } \\
\text { rodzeństwa: }\end{array}$ & & & & & & & & \\
\hline & brak & 9,5 & 9,0 & 6,84 & & 8,5 & 5,0 & 10,63 & \\
\hline & $1-2$ & 9,12 & 8,0 & 6,9 & 0,23 & 8,03 & 5,0 & 10,37 & 0,18 \\
\hline & 3 i więcej & 6,73 & 6,5 & 4,47 & & 11,9 & 6,5 & 12,91 & \\
\hline
\end{tabular}

Tabela 3

Różnice między grupami ze względu na wybory pozytywne

\begin{tabular}{lccc}
\hline \multirow{2}{*}{$\begin{array}{c}\text { Status materialny } \\
\text { rodziny }\end{array}$} & \multicolumn{2}{c}{$\begin{array}{c}\text { Wartość } p \text { dla porównań wielokrotnych (dwustronnych) } \\
\text { testem Kruskala-Wallisa: } H(2,192)=9,39 ; p=0,009\end{array}$} \\
\cline { 2 - 4 } & $\begin{array}{c}\text { Niezadowalający } \\
(\mathrm{R}: 81,397)\end{array}$ & $\begin{array}{c}\text { Wystarczający } \\
(\mathrm{R}: 92,806)\end{array}$ & $\begin{array}{c}\text { Bardzo dobry } \\
(\mathrm{R}: 119,47)\end{array}$ \\
\hline $\begin{array}{l}\text { Niezadowalający } \\
p\end{array}$ & $\mathrm{x}$ & 0,958 & 0,015 \\
\hline $\begin{array}{l}\text { Wystarczający } \\
p\end{array}$ & 0,958 & $\mathrm{x}$ & 0,026 \\
\hline $\begin{array}{l}\text { Bardzo dobry } \\
p\end{array}$ & 0,015 & 0,026 & $\mathrm{x}$ \\
\hline
\end{tabular}

Istotne różnice zachodzą między grupą badanych o statusie materialnym wystarczającym i bardzo dobrym $(p=0,026)$ oraz niezadowalającym i bardzo dobrym $(p=0,015)$. Nie uchwycono różnic między badanymi z wyborami pozytywnymi oceniającymi status materialny rodziny jako wystarczający i tymi, którzy oceniają go jako niezadowalający. Pomiary median $(M e)$ i średnich $(M)$ oraz średnich rang $(R)$ wskazują najwyższe wartości dla grupy badanych 
o statusie bardzo dobrym; otrzymano wysoką różnicę w porównaniu do grupy o statusie wystarczającym i niezadowalającym, przy czym badani z tej ostatniej grupy osiągnęli wartości najniższe.

\section{Status materialny rodziny a akceptacja dziecka przez rówieśników}

Aby uchwycić cechy różnicujące pozycje socjometryczne dziecka wśród rówieśników, przeprowadzono analizę za pomocą testu chi-kwadrat w schemacie międzygrupowym 3 (status materialny) $\times 3$ (rodzaj akceptacji). Wyłoniono podgrupy dzieci ze względu na rodzaj statusu materialnego rodziny (tabela 4).

Tabela 4

Zależność między akceptacja dziecka a statusem materialnym rodziny

\begin{tabular}{|c|c|c|c|c|c|c|c|}
\hline \multirow{3}{*}{$\begin{array}{c}\text { Status materialny } \\
\text { rodziny }\end{array}$} & \multicolumn{6}{|c|}{ Akceptacja dziecka w grupie } & \multirow{3}{*}{ Razem } \\
\hline & \multicolumn{2}{|c|}{ Wysoka } & \multicolumn{2}{|c|}{ Przeciętna } & \multicolumn{2}{|c|}{ Niska } & \\
\hline & $n$ & $\%$ & $n$ & $\%$ & $n$ & $\%$ & \\
\hline Niezadowalający & 7 & 24,14 & 7 & 24,14 & 15 & 51,72 & 29 \\
\hline Wystarczający & 47 & 37,90 & 39 & 31,45 & 38 & 30,65 & 124 \\
\hline Bardzo dobry & 23 & 58,97 & 8 & 20,51 & 8 & 20,51 & 39 \\
\hline Razem & & & & & & & 192 \\
\hline Wartość $\chi^{2}$ & 12,15 & & & & & & \\
\hline$d f$ & 4 & & & & & & \\
\hline$p$ & 0,016 & & & & & & \\
\hline
\end{tabular}

Otrzymany wynik okazał się istotny statystycznie $\left(\chi^{2}=12,15 ; d f=4 ; p=0,016\right)$. Udział dzieci z wysoką akceptacją jest zdecydowanie największy wśród tych najzamożniejszych i wyraźnie maleje wraz z obniżającym się statusem materialnym rodziny.

\section{Cechy różnicujące atrakcyjność dziecka}

Aby sprawdzić, czy status materialny współwystępuje z innymi badanymi cechami i czy różnicują one atrakcyjność dziecka w grupie, zastosowano w analizie model chi-kwadrat $\mathrm{w}$ schemacie międzygrupowym 3 (status materialny) $\times 2$ (płeć) oraz w schemacie międzygrupowym 3 (status materialny) $\times 2$ (struktura rodziny). 
Tabela 5

Zależność między statusem materialnym a płcią dziecka i struktura rodziny

\begin{tabular}{|c|c|c|c|c|c|c|c|c|}
\hline \multirow{3}{*}{$\begin{array}{c}\text { Status materialny } \\
\text { rodziny }\end{array}$} & \multicolumn{4}{|c|}{ Płeć dziecka } & \multicolumn{4}{|c|}{ Struktura rodziny } \\
\hline & \multicolumn{2}{|c|}{ Dziewczynki } & \multicolumn{2}{|c|}{ Chłopcy } & \multicolumn{2}{|c|}{ Pełna } & \multicolumn{2}{|c|}{ Samotnej matki } \\
\hline & $n$ & $\%$ & $n$ & $\%$ & $\mathrm{n}$ & $\%$ & $n$ & $\%$ \\
\hline Niezadowalający & 19 & 18,45 & 10 & 11,24 & 22 & 13,58 & 7 & 23,33 \\
\hline Wystarczający & 57 & 55,34 & 67 & 75,28 & 101 & 62,35 & 23 & 76,67 \\
\hline Bardzo dobry & 27 & 26,21 & 12 & 13,48 & 39 & 24,07 & 0 & 0,00 \\
\hline Razem & 103 & 100 & 89 & 100 & 162 & 100 & 30 & 100 \\
\hline Wartość $\chi^{2}$ & 8,392 & & & & 9,620 & & & \\
\hline$d f$ & 2 & & & & 2 & & & \\
\hline$p$ & 0,015 & & & & 0,008 & & & \\
\hline
\end{tabular}

Wśród dziewczynek zaobserwowano dwukrotnie wyższy udział badanych o statusie bardzo dobrym. Jest to zależność istotna statystycznie $\left(\chi^{2}=8,392\right.$; $d f=2 ; p=0,015)$, mogąca wpłynąć na to, że dziewczynki były częściej wybierane przez rówieśników. Istotny statystycznie wynik testu $\chi^{2}$ dla struktury rodziny $\left(\chi^{2}=9,620 ; d f=2 ; p=0,008\right)$ sugeruje, że cechy ze sobą współwystępują.

\section{OMÓWIENIE WYNIKów}

Celem opracowania było ustosunkowanie się do trzech problemów badawczych nawiązujących do obserwacji, że cechy związane z dzieckiem, jak i z rodziną różnicują zarówno wybory pozytywne, jak i negatywne badanych oraz pozycję socjometryczną dziecka wśród rówieśników. Na pierwsze pytanie badawcze, o to, które analizowane cechy różnicują pozytywne, a które negatywne wybory dziecka przez rówieśników, a jeśli tak, to czy mają istotne oddziaływanie, można odpowiedzieć, że wiek dziecka, struktura i miejsce zamieszkania rodziny oraz liczba posiadanego rodzeństwa okazały się bez znaczenia, zarówno dla wyborów pozytywnych, jak i negatywnych (tabela 2 ). Jedynie status materialny rodziny istotnie różnicuje liczbę pozytywnych wyborów dziecka, nie ma zaś znaczącego wpływu na wybory negatywne (tabela 3). Ponadto zaobserwowano, iż płeć nie jest cechą, która istotnie różnicuje liczbę wyborów pozytywnych i negatywnych. Warto jednak zwrócić uwagę na to, że dla wartości pozytywnych uzyskano wynik bliski granicy istotności statystycznej $(p=0,09)$. Wskazuje to na pewną tendencję, a dodatkowo, porównując mediany, widzimy, że dla dziewczynek ma ona wyższą wartość niż dla chłopców (zresztą średnia arytmetyczna także). Być może jest to pochodna faktu, że dziewczynek jest w badaniu więcej niż chłopców. Dodatkowym wytłumaczeniem może być obserwacja, że w tym wieku dziewczynki bardziej sympatyzują w grupie z dziewczynkami, a chłopcy z chłopcami. 
Na podstawie wyników można twierdzić, że następstwem odrzucenia dziecka przez grupę może być jego wycofanie się z zaangażowania $\mathrm{z}$ rówieśnikami czy unikanie szkoły (Buhs, Ladd, 2001). A przecież doświadczenia z rówieśnikami tworzą główny czynnik społeczny odpowiedzialny za ukształtowanie osobowości jednostki i jej socjalizację w kulturze (Harris, 1998). Gorsza sytuacja materialna rodziny może skutkować stopniową izolacją środowiskową, a dzieci, które nie mogą dorównać swoim rówieśnikom, mogą być nieakceptowane w szkole i poza nią (Matyjas, 2003).

Wyniki dla drugiego problemu badawczego: które cechy związane z dzieckiem i z rodziną istotnie różnicują pozycje socjometryczne dziecka wśród rówieśników, pokazują istotny udział statusu materialnego rodziny (tabela 4). Dzieci z wysoką akceptacją jest zdecydowanie najwięcej wśród tych oceniających status materialny rodziny jako bardzo dobry i ich liczebność wyraźnie maleje wraz z obniżającą się jego oceną. Odrzucenie ze strony kolegów z klasy wystarcza do wzbudzenia poczucia samotności społecznej w uczniach z trudnościami szkolnymi (Dołęga, 2003).

„Dzieci uczą się i postępują według wzorów dostarczanych im przez rodziców" (Matejek, 2013, s. 1128). Poważnym problemem rodzin ubogich wydaje się fakt, że rodzice stopniowo przestają być wzorem do naśladowania dla swoich dzieci. Dziecko nie ma gdzie nauczyć się entuzjazmu, zadowolenia i radości, ponieważ w jego rodzinnym domu często panuje apatia, zniechęcenie i narzekanie powodowane brakiem perspektyw (Forma, Wolska-Długosz, 2010). Stale dostrzegany przez dzieci skrajnie niski własny status społeczny, świadczący o małej atrakcyjności dla innych osób, i poczucie psychicznego wykluczenia z grupy mogą powodować deprywację ważnych potrzeb psychicznych: afiliacji, znaczenia, uznania w oczach innych. Mogą także utrwalać bierną lub agresywną postawę w relacjach interpersonalnych i dodatkowo uruchamiać mechanizmy obronne skłaniające do poszukiwania alternatywnych grup społecznych (Siwek, 2010).

Ostatnim etapem analizy było określenie, które z cech wykazują związek z cechami istotnie różnicującymi atrakcyjność dziecka wśród rówieśników w klasie. Efekty pokazują udział płci dziecka i struktury rodziny (tabela 5), w każdym przypadku zależność jest istotna statystycznie i sugeruje, że dziewczynki były lubiane przez rówieśników nieco bardziej niż chłopcy. To może oznaczać, że dziewczynki lepiej oceniają sytuację materialną rodziny niż chłopcy, dla których wskaźnikiem atrakcyjności wśród rówieśników nie są cechy osobowościowe, lecz stan posiadania nowoczesnego sprzętu mobilnego, markowych ubrań, spędzania wakacji poza granicami kraju. Wielu badaczy traktuje niskie zasoby ekonomiczne rodziny jako czynnik ryzyka, który zgodnie $\mathrm{z}$ jedną z hipotez oddziałuje nie tylko na rodziców dzieci (Guerin, Hennessy, 2008). Otrzymane wyniki są zgodne z efektami badań Dąbrowskiej-Jabłońskiej (2002), w których chłopcy byli częściej niż dziewczynki odrzucani przez klasę. Wyniki ujawniają 
ponadto, że dzieci z rodzin samotnych matek są gorzej sytuowane materialnie (nie ma wśród nich żadnego dziecka o statusie bardzo dobrym). Uzyskane efekty dla trzeciego problemu badawczego potwierdzają wcześniejsze obserwacje, że w badaniu tym jedynym czynnikiem różnicującym atrakcyjność dziecka w grupie rówieśniczej jest status materialny rodziny.

Podsumowując: dzięki zastosowaniu narzędzia psychologicznego oraz przeprowadzeniu analiz statystycznych zidentyfikowano cechy różnicujące atrakcyjność dziecka wśród rówieśników. Mówiąc inaczej: niektóre cechy opisujące dzieci w wieku szkolnym wywodzące się z małych miast i wsi warunkują ich pozycję socjometryczną w klasie szkolnej. Sytuacja ekonomiczna rodziny warunkuje atrakcyjność dziecka w grupie. Dzieci bardziej interesują się tymi rówieśnikami, którzy są lepiej sytuowani materialnie. Ubóstwo znacząco wiąże się z niekompletną strukturą rodziny oraz z płcią dziecka, które dodatkowo różnicują akceptację dziecka przez klasę szkolną.

Generalnie wnioskiem $z$ badań jest potwierdzenie obserwacji, że dzieci atrakcyjne dla swoich rówieśników to te, które są lepiej sytuowane materialnie. Ponadto:

- chłopcy, bez względu na ocenę statusu materialnego rodziny, częściej niż dziewczynki otrzymują wybory negatywne,

- bardziej atrakcyjne dla rówieśników są dziewczynki z rodzin zamożniejszych niż chłopcy, bez względu na sytuację materialną rodziny.

\section{Implikacje do praktyki wychowawczej}

Odrzucenie dziecka przez rówieśników można traktować jako wczesny prognostyczny wskaźnik zaburzeń jego rozwoju (Kulawska, 2013). Może ono skutkować poważnymi problemami w dalszym życiu szkolnym i pozaszkolnym. Wyniki tych badań stanowią wyzwanie dla podejmowania działań przez nauczycieli, wychowawców, pedagogów w celu integracji klasy szkolnej. Praca wychowawcza powinna być skoncentrowana na budowaniu pozytywnego klimatu grupy dzięki strategiom tworzenia jej spójności i wspólnych zasad funkcjonowania. Pomoc dzieciom zagrożonym odrzuceniem, polegająca na okazywaniu im większej uwagi i zainteresowania oraz rozwijaniu ich kompetencji społecznych, będzie zachęcać rówieśników do rozpoznawania podobieństwa między sobą. Co więcej, zwiększy zaufanie w grupie rówieśniczej i będzie prowadzić do zmiany nastawienia klasy wobec dzieci z rodzin mniej zamożnych.

\section{Bibliografia}

Apanowicz, J. (2002). Metodologia ogólna. Gdynia: Wydawnictwo Bernardinum. Bartczak, B. (2014). Współczesne zagrożenia rozwoju dzieci i młodzieży. Pobrano z: http://www.sp9.lm.pl/Artykuly/Wspolczesne zagrozenia rozwoju dzieci i mlodziezy.pdf 
Białas, A. (2001). Bieda i ubóstwo: konsekwencje dla dziecka i rodziny. Opieka, Wychowanie, Terapia, 2, 46, 5-9.

Buhs, E. S., Ladd, G. W. (2001). Peer Rejection as an Antecedent of Young Children's School Adjustment. An Examination of Mediating Processes. Development Psychology, 24, 815-823.

Cudak, H., Kowolik, P., Pindera, M. (1999). Subiektywne i obiektywne ubóstwo materialne w rodzinie polskiej. Auxilium Sociale - Wsparcie Społeczne, 3-4, $165-172$.

Dąbrowska-Jabłońska, I. (2002). Sytuacja szkolna dziecka urodzonego w zamartwicy. Rodzaje zagrożeń i możliwości pomocy. Opole: Wydawnictwo UO.

Dodge, K. A., Lansford, J. E., Burks, V. S., Bates, J. E., Pettit, G. S., Fontaine, R., Price, J. M. (2003). Peer rejection and social information - processing factors in the development of aggressive behavior problems in children. Child Development, 74(2), 374-393.

Dołęga, Z. (2003). Samotność młodzieży - analiza teoretyczna i studia empiryczne. Katowice: Wydawnictwo UŚ.

Elder, G., Eccles, J., Ardelt, M., Lord, S. (1995). Inner-City Parents under Economic Pressure: Perspectives on the Strategies of Parenting. Journal of Marriage and the Family, 57, 771-784.

Forma, P., Wolska-Długosz, M. (2010). Zadania pedagoga w zakresie pomocy rodzinie ubogiej. Studia Pedagogiczne, 19, 319-329.

Guerin, S., Hennessy, E. (2008). Przemoc i prześladowanie w szkole. Gdańsk: Gdańskie Wydawnictwo Psychologiczne.

Harris, J. R. (1998). Geny czy wychowanie. Warszawa: Wydawnictwo Jacek Santorski \& CO.

Harwas-Napierała, B., Trempała, J. (red.) (2006). Psychologia rozwoju człowieka. Charakterystyka okresów życia człowieka. Warszawa: PWN.

Jundził, L. E. (1998). Potrzeby psychiczne dzieci i młodzieży. Gdańsk: Wydawnictwo UG.

Kotowska, I. E., Matysiak, A., Styrc, M. (2010). Second European Quality of Life Survey. Family Life and Work [raport]. Pobrane z: www.eurofound.europa. eu/pubdocs/2010/02/en/1/EF1002EN.pdf

Kulawska, E. (2013). Uwarunkowania i konsekwencje odrzucenia dziecka w wieku szkolnym przez grupę rówieśniczą. Seminare. Poszukiwania naukowe, 33, 193-207.

Kwak, A. (2008-2009). Młodzież a rodzina. Roczniki Socjologii Rodziny. Rodzina i młodzież. Teoria i badania, XIX, 51-70.

Lenarczyk, M. (2004). Rodzina a zagrożenia rozwojowe dziecka ze środowiskowego ogniska wychowawczego w okresie transformacji ustrojowej. Opieka, Wychowanie, Terapia, 1-2, 31-39.

Matejek, J. (2013). Rola seniorów w rodzinie w procesie organizacji czasu wolnego dzieci. W: M. Bargel, E. Janigova, E. Jarosz, M. Juzl (red.), Socialni 
pedagogika $v$ kontextu zivotnich etap cloveka (s. 1127-1136). Brno: Institut mezioborovych studii.

Matyjas, B. (2003). Dzieciństwo $w$ rodzinie bezrobotnych $w$ środowisku małego miasta. Kielce: Wydawnictwo Akademii Świętokrzyskiej.

Mazur, J., Woynarowska, B. (2004). Mierniki nierówności społecznych w badaniach ankietowych młodzieży szkolnej. Przegląd Epidemiologiczny, 58, 377-390.

McWhirter, J. J., McWhirter, E. H., McWhirter, A. M., McWhirter, B. T. (2008). Zagrożona młodzież: ujęcie kompleksowe dla pracowników poradni, nauczycieli, psychologów i pracowników socjalnych. Warszawa: Wydawnictwo Edukacyjne PARPA.

Miller, J. E., Davis, D. (1997). Poverty History, Marital History, and Quality of Children's Home Environments. Journal of Marriage and the Family, 59, 996-1007.

Napora, E. (2015, V). Factors Affecting Socialization from the Perspective of the Study of a School Child. Referat na Society. Integration. Education. International Scientific Conference, Rēzekne, Łotwa. Pobrane z: http://journals.ru.lv/index.php/SIE/article/view/463/450

Napora, E. (2015). Pogoda dla klasowych bogaczy. Psychologia w Szkole, 3, 87-94. Napora, E., Garbiec, P. (2015, V). Atrakcyjność dziecka w grupie z perspektywy efektu św. Mateusza. Referat na Z Psychologią po zdrowie. Profilaktyka i promocja zdrowia - mit czy rzeczywistość?, Gdańsk.

Napora, E., Kozerska, A., Schneider, A. (2014). Parentyfikacja dziadków czynnikiem resilience $\mathrm{w}$ funkcjonowaniu rodziny samotnej matki - przegląd badań. Kultura i Edukacja, 1(101), 51-71.

Napora, E., Pękala, B. (2014). Wsparcie i komunikacja matek czynnikiem prężności w funkcjonowaniu córek wśród rówieśniczek. Polskie Forum Psychologiczne, 19(3), 371-386.

Niebrzydowski, L. (1989). Psychologia wychowawcza. Samoświadomość, aktywność, stosunki interpersonalne. Warszawa: PWN.

Obuchowska, I. (2000). Rozwój psychiczny i społeczny. W: B. Woynarowska (red.), Zdrowie i szkoła. (s. 52-62). Warszawa: Wydawnictwo Lekarskie PZWL.

Pawłowska, R. (1994). Izolacja społeczna i odrzucenie dziecka przez grupy wychowawcze. Problemy Opiekuńczo-Wychowawcze, 3, 34-35.

Raczkowska, J. (1994). Pedagogiczne problemy bezrobocia. Problemy Opiekuńczo-Wychowawcze, 4, 19-26.

Radziwiłłowicz, W. (2012). Czynniki ryzyka oraz różnorodność obrazu klinicznego depresji u dzieci i młodzieży. [Wykład] Pobrano z: https://knempiria. wordpress.com/tydzien-zdrowia-psychicznego-2014-2/

Samdal, O., Dür, W. (2000). The school environment and the health of adolescents. W: C. Curie, K. Hurrelmann, W. Settertobulte, R. Smith, J. Todd 
(red.), Health and health behaviour among young people. Health Policy for Children and Adolescents (HEPCA) Series 1 (s. 49-64). Copenhagen: WHO. Schaffer, H. R. (2006). Rozwój społeczny, dzieciństwo i młodość. Kraków: Wydawnictwo Uniwersytetu Jagiellońskiego.

Siwek, S. (2010). Czynniki społeczne w genezie nieprawidłowego rozwoju i zachowania. Acta Universitatis Lodziensis Folia Psychologica, 14, 19-43.

Sztumski, J. (2006). Problemy społeczne wynikające z sytuacji dzieci i młodzieży w procesie przemian zachodzących w Polsce po roku 1989. W: J. Sztumski (red.), Pokolenie wygranych? Ciag dalszy badań nad sytuacją dzieci i młodzieży $w$ procesie transformacji. Katowice: Wydawnictwo Naukowe „Śląsk”.

Urban, B. (2005). Zachowania dewiacyjne młodzieży w interakcjach rówieśniczych. Kraków: Wydawnictwo Uniwersytetu Jagiellońskiego.

Zawada, A. (2002). Sytuacja szkolna dzieci wychowujących się w rodzinach o niskim statusie ekonomicznym. Auxilium Sociale, 1, 297-305.

Zawada, I. (2013). Przestrzeń edukacyjna klasy szkolnej. Roczniki Edukacyjne, 2, 75-94. 